\title{
Cost-of-Living Adjustment Clauses in Union Contracts: A Summary of Results
}

\author{
Ronald G. Ehrenberg, Cornell University and National \\ Burean of Economic Research \\ Leif Danziger, Tel Aviv University
}

Gee San, Cornell University

Our paper provides an explanation why cost-of-living adjustment (COLA) provisions and their characteristics vary widely across U.S. industries. We develop models of optimal risk sharing between a firm and union to investigate the determinants of a number of contract characteristics. These include the presence and degree of wage indexing, the magnitude of deferred noncontingent wage increases, contract duration, and the trade-off between temporary layoffs and wage indexing. Preliminary empirical tests of some of the implications of the model are described. One key finding is that the level of unemployment insurance benefits appears to influence the level of layoffs and the extent of COLA coverage simultaneously.

\section{Introduction}

Cost-of-living escalator clauses in union contracts tie, or index, workers' wages to some indicator of prices, such as the Consumer Price Index. The first major U.S. labor contract to contain such a clause was the 1948 contract between General Motors and the United Automobile Workers

Our research has been supported by a grant to Ehrenberg from the National Science Foundation. Without implicating them for what remains, we are grateful to David Card, Daniel Hamermesh, Wallace Hendricks, Dan Saks, a referee, and the editors for their comments on earlier drafts.

[Journal of Labor Economics, 1983, vol. 1, no. 3]

(C) 1983 by The University of Chicago. All rights reserved.

0734-306X/83/0103-0001\$01.50 
(UAW). ${ }^{1}$ Such provisions became prevalent during the inflation that accompanied the Korean War, but interest in them waned as prices stabilized during the early 1950 s. As a result, by January 1955, only $23 \%$ of workers covered by major collective bargaining agreements-agreements that included 1,000 or more workers-were also covered by contracts that contained cost-of-living provisions.

Prices rose during the late 1950s, and coverage expanded as large national contracts in steel, aluminum and can, railroads, and electrical equipment incorporated such provisions. The relative price stability of the early 1960 s led to a reduction in coverage; indeed, the cost-of-living provision was dropped from the steel contract in 1962. Since 1966, however, high rates of inflation have been associated with steady increases in coverage: during the 1976-81 period roughly $60 \%$ of workers covered by major union contracts were also covered by cost-of-living provisions.

The growth in the prevalence of cost-of-living adjustment (COLA) provisions has rekindled both academic and public interest in the topic, and this interest has taken a number of forms. ${ }^{2}$ First, attention has been directed towards the role of COLAs in the inflationary process. During the 1970s the wages of employees in heavily unionized industries who were covered by COLAs grew significantly relative to the wages of other employees in the economy (see, e.g., Kosters 1977; Mitchell 1980). In addition, the growing prevalence of multiyear contracts with COLA provisions has been shown to have reduced the responsiveness of the aggregate rate of wage inflation to the aggregate unemployment rate; increases in the rate of unemployment now "buy" less reduction in wage inflation than they did in the 1960 s. $^{3}$ Because of these facts, COLAs are thought by some to be one cause of the persistent high rates of inflation we have experienced in the United States-even though COLAs typically provide workers with much less than $100 \%$ protection against inflation. ${ }^{4}$

Second, attention has been directed to the role COLAs may play in reducing the level of strike activity in the economy. One reason that a collective bargaining negotiation may not be settled before a strike is that the employer's and the union's forecasts and perceptions about future

${ }^{1}$ See Douty (1975) for a more complete discussion of the history of cost-ofliving clauses in union contracts in the United States.

${ }^{2}$ We say rekindled, since academic interest in the effect of indexation schemes, such as COLAs, on the economy goes back at least as far as Alfred Marshall (1886).

${ }^{3}$ On the growing insensitivity of the aggregate rate of wage inflation to unemployment, see Tobin (1980). On the insensitivity of deferred wage increases, including COLAs, in union contracts to unemployment, see Mitchell (1978).

"For evidence on the "yield" from COLAs, see Shefer (1979). We will return to this point below. Farber (1981), Kahn (1981), Vroman (1982), and Hendricks and Kahn (1983), have presented evidence on the role of COLAs in the inflationary process. 
rates of inflation may differ substantially. A COLA provision, which ties the wage over the course of a contract to future prices, reduces the need for the employer's and the union's price forecasts to coincide and thus may reduce the likelihood of a strike occurring. ${ }^{5}$ Since strike activity involves lost output, COLAs may well have a positive effect on aggregate output.

Third, numerous economists have focused on the implications of COLAs for macroeconomic stabilization policy. ${ }^{6}$ Among the questions they ask are, "Can indexing schemes protect the aggregate economy from real or monetary shocks?" "How does the degree of indexing influence government stabilization policy?" and, "What is the optimal degree of indexing, from the perspective of macrostabilization or aggregate efficiency policy?" Their objective is to show that in a world of uncertain future outcomes, where it is impossible to establish contingent contracts that cover every possible state of the world, COLAs do lead to welfare gains.

Finally, another stream of research has focused on the implications of COLAs for microeconomic efficiency, in particular the sharing of risks of uncertain outcomes by firms and workers. These papers are in the tradition of the "implicit contract" literature, and they focus on optimal indexation from the perspective of a microlevel decision making unit. ${ }^{7}$ In particular, they examine the effects of such variables as the expected rate of inflation, uncertainty, employee risk aversion, the cost of indexing, and nonlabor income on the optimal degree of indexing.

It is somewhat surprising that, although the latter two streams of literature have focused on the determination of the optimal degree of indexing at the aggregate and micro levels, there have been only a few attempts to see if these theories can be used to explain either the varying prevalence of COLAs in the aggregate U.S. economy over time or why the prevalence of COLAs and their characteristics vary across industries at a point in time. ${ }^{8}$ Bureau of Labor Statistics data indicate quite clearly

${ }^{5}$ For details of this argument and aggregate evidence that the presence of COLAs reduces strike activity, see Kaufman (1981). See also Mauro (1982) for a similar argument and empirical evidence using individual contract negotiation data.

${ }^{6}$ Important contributions here include Gray (1976, 1978), Barro (1977), Fisher $(1977 a, 1977 b)$, and Blanchard (1979).

7 The relevant papers here are Shavell (1976), Azariadis (1978), and Danziger (1980, 1983).

${ }^{8}$ See Estenson (1981), Kahn (1981), and Hendricks and Kahn (1983); these studies are primarily empirical in nature; they do not provide rigorous analytical models that permit them to identify all of the forces that influence COLAs. Our paper is more in the tradition of Card's (1981, 1982) work, although in some respects (noted below) our model is more general and his empirical analyses use Canadian contract data. 
that the prevalence of COLAs in major collective bargaining agreements varies widely across industries (see, e.g., LeRoy 1981). Moreover, one cannot attribute these differences solely to differences in union strength; for example, a strong national union exists in bituminous coal mining and strong local unions exist in construction, but in neither industry are there many contracts with COLAs.

Our paper seeks to provide an explanation why the prevalence and characteristics of COLA provisions vary widely across U.S. industries. We do this in the context of models of optimal risk sharing between a firm and a union that allow us to investigate the determinants of a number of characteristics of union contracts. In addition to the degree of wage indexing, we focus on the determinants of deferred nominal or real wage increases in multiperiod contracts that are not contingent on the realized price level, on the determinants of the duration of labor contracts, and on the interrelationship between contract duration and wage indexation. Moreover, to integrate our research more fully into the implicit contract literature, we investigate the influence of parameters of the unemployment insurance (UI) system on the extent of indexing and the level of temporary layoffs. After developing a series of theoretical models, we proceed to describe our attempts to test some of the hypotheses these models generate, using individual contract data and pooled cross-section time-series data at the two-digit manufacturing industry level.

In the main, this paper represents a summary and extension of research reported in a longer paper (Ehrenberg, Danziger, and San 1982). Space does not permit us to describe all of the details of our research or to provide proofs of propositions here. Interested readers should see the longer paper for details and derivations.

\section{A 1-Period Model with Fixed Employment}

Consider first the following simple 1-period model. A union and an employer must decide on the provisions of a collective bargaining agreement before the aggregate price level is known. At the time negotiations take place, the aggregate price level, $p$, is equal to unity, but during the period that the contract will cover the price level is uncertain; the expected value of $p$ during the period is denoted by $\bar{p}$ and its coefficient of variation by $\phi_{p}>0$. We also treat the firm's production function, its demand curve, and the prices of its nonlabor inputs as being uncertain, in a manner to be specified below.

In principle, an optimal risk-sharing arrangement would make both the wage and the employment level contingent on the realized outcomes of the aggregate price level, the firm's productivity, its demand curve (as proxied perhaps by its output price level), and the price of its nonlabor inputs. For now, however, we assume that the employment level is predetermined and equal to the number of union members, $N$. Thus there 
is no temporary layoff unemployment in this model (we will relax this assumption in Sec. VI below).

In addition, we assume that when the employer and the union negotiate a wage schedule $w$, this wage is contingent on, or indexed only to the aggregate price level

$$
w=w(p) .
$$

Virtually all contracts with COLAs in the United States are structured in this manner and only rarely are wages explicitly tied to future productivity, industry price levels, or input price levels. ${ }^{9}$ Our failure to observe more contracts that also tie wages to these variables undoubtedly reflects factors such as moral hazard (firms may have some control over their output prices) and the costs of obtaining information and enforcing such contracts (the difficulties involved in measuring productivity and demand shifts, etc.). ${ }^{10}$

Suppose that workers are risk averse and have cardinal utility functions of the form $U[(w / p)+M]$, with $U^{\prime}>0$ and $U^{\prime \prime}<0$. Utility depends on the worker's real income in a period, with $M$ being the level of real nonwage labor income. For now we treat $M$ as being identically equal to zero; later we will indicate how the extent that it varies with the price level effects the optimal degree of indexing of wages.

The firm uses labor $(L)$ and a composite variable input $(X)$ to produce output $(Q)$ via the production function relationship:

$$
Q=f\left(L, X, e_{1}\right) .
$$

Here $e_{1}$ is a random productivity shock whose realized value becomes known only after the contract is signed. That is, productivity is uncertain at the time of the negotiations. For simplicity, we assume that $e_{1}$ is independent of both the distribution and realization of the aggregate price level.

Demand for the firm's output is assumed to depend both on the price charged by the firm and on the amount of unanticipated inflation, with the latter defined by

$$
\hat{p}=p / \bar{p} .
$$

9 There are, of course, exceptions to this statement. The "ton tax" method of financing fringe benefits that prevailed for many years in the bituminous coal industry is an example of a contract where compensation is contingent upon productivity; as is well known, this scheme was designed to reduce employers' incentives to substitute capital for labor. Similarly, the recent UAW contract with Chrysler and the airline contracts with Eastern Airlines, that tie compensation to profits, implicitly are contingent on all uncertain events.

${ }^{10}$ For more on this point, see the discussion between Barro (1977) and Fisher $(1977 a)$. 
The notion is that unanticipated inflation in the aggregate price level may lead to increases in the demand for some firms' products and decreases in the demand for others. ${ }^{11}$

Specifically, we assume that the inverse demand function can be written

$$
q=p g\left(Q, \hat{p}, e_{2}\right),
$$

where $q$ is the price of the firm's product, $e_{2}$ is a random demand shock whose realization becomes known only after negotiations are concluded, and the inclusion of $Q$ allows the firm to face a downward-sloping demand curve. The demand shock is assumed to be independent of the distribution of the aggregate price level and, accordingly, we assume that the real price $(q / p)$ the firm can charge for its product at any specified output level is independent of the expected inflation rate.

The price of the variable input $X$ is also assumed to depend on the amount of anticipated inflation and is given by

$$
z=p h\left(\hat{p}, e_{3}\right),
$$

where $z$ is the price of the input and $e_{3}$ is a random cost shock. As with the other shocks, the realized value of $e_{3}$ becomes known only after the negotiations are completed and $e_{3}$ is assumed to be independent of the distribution of the aggregate price level (although it need not be independent of $e_{1}$ and $e_{2}$ ). The firm is assumed, in (5), to be a price taker in the market for the other input for expositional convenience only.

Because employment $(L)$ is always equal initially to the number of union members, the firm's profit $(\pi)$ is given by

$$
\pi=p g\left[f\left(N, X, e_{1}\right), \hat{p}, e_{2}\right] f\left(N, X, e_{1}\right)-p h\left(\hat{p}, e_{3}\right) X-w N .
$$

The variable input $X$ is chosen after the realized values of all of the random variables are known and, conditional on them, $X$ is always chosen by the firm to maximize profits. Assuming an interior solution always exists, this requires that

$$
\partial \pi / \partial X=0 \quad \forall p \text { and } e
$$

where $e=\left(e_{1}, e_{2}, e_{3}\right)$.

The firm's utility from real profits is given by $V(\pi / p)$, where $V$ is a cardinal utility function, $V^{\prime}>0$, and $V^{\prime \prime}<0(=0)$ if the firm is risk averse (risk neutral). Given a wage schedule $w(p)$, the firm's expected utility

${ }^{11}$ The key role of unanticipated inflation in the indexing decision has been previously noted by Card (1981). 
obviously depends on the distributions of all of the random variables in the model.

The goal of the union is to maximize the representative worker's expected utility, while the goal of the firm is to maximize its expected utility. It is beyond the scope of this paper to model the bargaining process and show how it may lead to an agreed upon contract. ${ }^{12}$ The only assumption that we make here is that the parties will reach a contract that provides for efficient sharing of all risks stemming from unanticipated inflation. Such contracts can be obtained by choosing a wage indexing schedule that maximizes

$$
\mathfrak{E}=\underset{p}{E}[U(w / p)]+\lambda \underset{p, e}{E}[V(\pi / p)]
$$

where $\lambda$ is a parameter that indicates the "share of the pie" that the employer receives. Other things equal, higher values of $\lambda$ reflect greater employer bargaining power.

It is useful to define the following functions:

$\epsilon \equiv \frac{d w}{d p} \frac{p}{w} \quad$ the elasticity of the wage rate, $w$, with respect to the $d p w$ aggregate price level, $p$;

$a \equiv \frac{\partial g}{\partial \rho} \quad$ the elasticity of the firm's demand curve, $g$, with respect to unanticipated inflation, $\hat{p}$;

$b \equiv \frac{\partial b}{\partial \rho} \quad$ the elasticity of other input prices, $b$, with respect to unanticipated inflation, $\hat{p}$;

$\eta \equiv-\frac{\partial Q}{\partial g} \frac{g}{Q} \begin{aligned} & \text { the (absolute value) of the elasticity of demand with re- } \\ & \text { spect to the firm's real price, } q / p ;\end{aligned}$ $\psi \equiv 1-\eta^{-1}$ the elasticity of total revenue with respect to the firm's $\beta \equiv \frac{\partial f}{\partial X} \frac{X}{f} \quad \begin{array}{ll}\text { the elasticity of output with respect to the other input, }\end{array}$ $A \equiv \frac{a-b \psi \beta}{1-\psi \beta}$ the elasticity of the firm's real value added with respect $S \equiv \frac{U^{\prime \prime}}{U^{\prime}} \frac{w}{p} \quad$ the workers' relative risk aversion.

In general each of these variables is a function and not a parameter. In what follows when we talk about a change in any one of them we mean a shift in the whole function.

The elasticity of the wage rate with respect to the aggregate price level, $\epsilon$, is a measure of the extent to which the wage rate is indexed to the

${ }^{12}$ See Svejnar (1982) for an attempt to accomplish this objective. 
price level. It is straightforward to show (see Ehrenberg, Danziger, and San 1982, app. A) that maximization of (8) subject to (1)-(7) yields that the optimal degree of indexing is given by

$$
\epsilon=1-\frac{\underset{e}{E} V^{\prime \prime} A(\pi+w N / p)}{\underset{e}{S E V^{\prime}-(w N / p) \underset{e}{E} V^{\prime \prime}} .}
$$

That is, the optimal degree of wage indexing depends both on factors exogenous to the bargaining process (such as the extent of employer and employee risk aversion) and on the outcome of the bargaining process itself (such as the level of wages) and hence the parties' relative bargaining power.

Note that if the firm is risk neutral $\left(V^{\prime \prime}=0\right)$, indexing is complete $(\epsilon=1)$. In this case, the real wage is independent of the aggregate price level and the firm fully insulates workers against inflation risks. Since collective bargaining agreements seldom call for complete indexing, throughout the rest of the paper we assume that the firm is risk averse.

It is apparent from (9) that the elasticity of the firm's real value added with respect to the aggregate price level, $A$, is a key variable in determining the extent of indexation. If $A$ is greater (less) than zero, so that increases in the aggregate price level increase (decrease) the firm's real value added, then the firm shares the rewards (costs) of inflation by providing workers with a more than (less than) complete indexing. That is, indexing is not necessarily less than full; optimal risk-sharing agreements may call for workers to be "overcompensated" for inflation. Of course, if inflation is neutral in the sense that the firm's demand and the price of nonlabor inputs are unaffected by unanticipated inflation $(a=b=0$ for all $e$ ), then $\epsilon=1$. In this special case inflation risk affects the firm only through its effect on real wages, and full indexing eliminates all inflation risk for both workers and firm. The firm is still exposed to other risks $(e)$, but since these are not related to inflation they cannot be alleviated by indexing to the aggregate price level.

The first column in table 1 summarizes the main comparative static results that follow from equation (9); how changes in various factors influence the optimal degree of indexing. An increase in the elasticity of the demand curve with respect to unanticipated inflation $(a)$ increases the degree of indexing since the larger the increase in real value added that results from an unanticipated increase in prices, the larger the pie available to share with workers. Conversely, the larger the elasticity of other input prices with respect to unanticipated inflation $(b)$, the more disadvantageous is the unanticipated inflation to the firm, and therefore the smaller the degree of wage indexing that occurs.

The effect of the elasticity of the firm's demand curve with respect to 
its rea! price, $\eta$, depends upon the relationship of $a$ and $b$. To see this, consider first the special case where these two elasticities are equal $(a=b)$. In this case, unanticipated inflation causes identical percentage changes in the real marginal revenue product of nonlabor inputs (MRP) and in the inputs' real price. Since the input level, $X$, is always chosen so that its real marginal revenue product equals its real price (eq. [7]), there will be no adjustment in the amount of the input used and hence in output. In terms of figure $1 a$ the firm will move from $M$ to $N$. Consequently, the value of $\eta$ does not affect the change in real value added in this case and $\epsilon$ will be independent of $\eta$.

In contrast, if $a$ is greater than $b$, a higher unanticipated inflation implies a higher percentage increase in $M R P$ than in $z$. In order to maintain the equality between the variable input's marginal revenue product and its price, the amount of the input and hence output must be higher. The magnitude of this effect will be larger the higher the elasticity of the marginal revenue product curve with respect to the input. This is illustrated in figure $1 b$ where we assume that $a$ is greater than $b$. The firm will move from $M$ to $O$ with a less elastic demand curve and from $M$ to $P$ with a more elastic one. The latter case is associated with a greater increase in real value added and thus we should observe a higher degree of indexing associated with it. Since, other things equal, higher values of the elasticity of the firm's demand curve with respect to its real price are

\section{Table 1}

Summary of Main Results:

1-Period Fixed Employment Model

\begin{tabular}{|c|c|c|}
\hline Increase in Parameter & $\begin{array}{c}\text { Degree } \\
\text { of Indexing } \\
(\epsilon)\end{array}$ & $\begin{array}{c}\text { Probability of } \\
\text { Indexing } \\
(\hat{B})\end{array}$ \\
\hline $\begin{array}{l}\text { Elasticity of demand curve with respect to } \\
\text { unanticipated inflation }(a)\end{array}$ & + & + \\
\hline $\begin{array}{l}\text { Elasticity of other input prices with } \\
\text { respect to unanticipated inflation }(b)\end{array}$ & - & - \\
\hline $\begin{array}{l}\text { Elasticity of firm demand with respect to } \\
\text { real price }(\eta)\end{array}$ & $\underline{0}$ as $a \frac{\geq}{<} b$ & $\stackrel{+}{0}$ as $a \frac{\geq}{<} b$ \\
\hline $\begin{array}{l}\text { Elasticity of output with respect to other } \\
\text { input }(\beta)\end{array}$ & $\underline{0}$ as $a \underset{<}{<} b$ & $\underline{0}$ as $a \geq b$ \\
\hline Employee risk aversion $(S)$ & $\underline{0}$ as $A \leq 0$ & + \\
\hline Expected inflation $(\bar{p})$ & 0 & 0 \\
\hline $\begin{array}{l}\text { Coefficient of variation in } \\
\text { expected inflation }\left(\phi_{p}\right)\end{array}$ & 0 & + \\
\hline Costs of indexation $\left(c_{i}\right)$ & $\ldots *$ & - \\
\hline $\begin{array}{l}\text { Pure random variation in demand, } \\
\text { productivity, and other input prices } \\
\left(\phi_{v}\right) \dagger\end{array}$ & $\overline{+}$ as $A(S-R) \frac{<0}{>}$ & + \\
\hline
\end{tabular}

* The effect will depend on the distribution of the cost between workers and firm as well as on many parameters of the model.

† See the text for the specific assumptions necessary to obtain these results. 
associated with more elastic marginal revenue product curves for the variable input, higher elasticities of the demand curve will lead to higher values of wage indexing in this case. In contrast, if $a$ is less than $b$, similar reasoning shows that increasing the elasticity of the firm's demand curve with respect to its own price will reduce the extent of indexing.

The key point here, then, is that the firm's elasticity of demand with respect to its own real price $(\eta)$ does affect the optimal degree of wage indexing, but that the direction of the effect depends upon the relationship of $a$ and $b$, the elasticities of the firm's demand curve, and its other input prices with respect to unanticipated inflation. If $a$ is greater (less) than $b$, higher values of $\eta$ lead to more (less) wage indexing. Since a higher elasticity of output with respect to the variable input $(\beta)$ is also associated with a higher elasticity of the variable input's $M R P$ curve, analogous results follow with respect to this variable. That is, increases in $\beta$ are associated with increases (decreases) in the extent of indexation if $a$ is greater (less) than $b$.

Several other results are easier to explain. First, the more risk averse workers are, the greater is the value to them of smoothing variations in the real wage. Consequently, increased risk aversion $(S)$ is associated with values of $\epsilon$ closer to unity. ${ }^{13}$

Second, the optimal degree of indexing is independent of both the expected level of inflation $(\bar{p})$ and the uncertainty of inflation $\left(\phi_{p}\right)$. These results follow directly from the assumption that all real variables are unaffected by the distribution of $p$, as opposed to its realized value. ${ }^{14}$

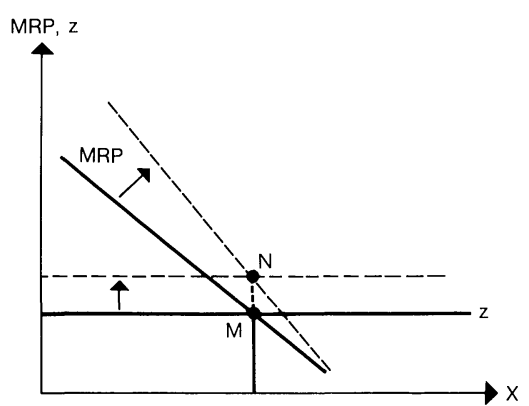

a

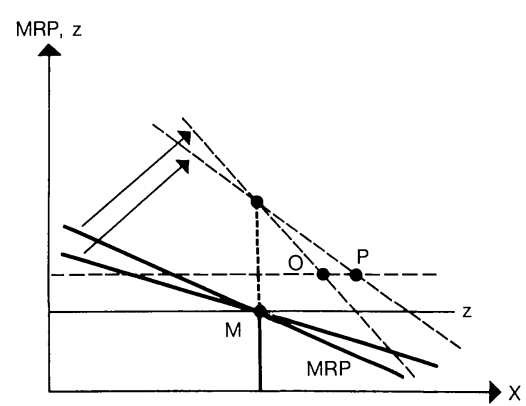

b

FIGURE 1

${ }^{13}$ Hendricks and Kahn (1983) erroneously concluded that increased employee risk aversion always would lead to increased wage indexing. This is true only if the initial degree of indexing is less than unity.

${ }^{14}$ In a more general model in which the aggregate price shock has some joint distribution with the firm's demand shock and the input price shock, the result with respect to the coefficient of variation would fail to hold. In such a model, our parameters $a$ and $b$ would measure the derivatives of the conditional inferences of demand and input prices with respect to the aggregate price level. The change 
Finally, the optimal degree of indexing depends also on the residual uncertainty in real value added - the uncertainty in real value added caused by shocks to productivity, demand, and other input prices. Unfortunately, its effect on the optimal degree of indexing depends on many parameters in the model and on how they change. If one further assumes, however, that $a, b, \eta, \beta, A$, and $R$ (where $R=-\left[V^{\prime \prime} k V^{\prime}\right][\pi / p]$ ) is the firm's relative risk aversion) are constant, it can be shown that

$$
\partial \epsilon / \partial \phi_{V} \leq 0 \quad \text { as } \quad A(S-R) \frac{\leq}{>},
$$

where $\phi_{v}$, the coefficient of variation of real value added, is used as a measure of the residual uncertainty in real value added. If employee relative risk aversion $(S)$ is greater than employer relative risk aversion, this implies that increased residual uncertainty makes indexing less perfect (further from unity). ${ }^{15}$

Before concluding this section, two extensions of the model warrant a brief discussion. First, suppose that we relax the assumption that the employee's nonlabor income, $M$, is always zero. Assuming that the level of nonlabor income is positive, its effect on the optimal degree of wage indexing depends on how its varies with the price level. If the level of nonlabor income is fixed in nominal terms, then to stabilize the sum of real wages and real nonlabor income will require a greater degree of wage indexing than in the absence of the nonlabor income, assuming that indexing is positive. In contrast, if the nonlabor income is fixed in real terms (perfectly indexed), then any desired degree of real income stabilization (not equal to perfect stabilization) can be achieved with now less perfect wage indexing ( $\epsilon$ further from unity).

Second, suppose we now allow wages to be indexed not only to the aggregate price level, but also to the shocks to the firm's productivity, demand curve, and input prices. In this case, one can show that if employers are risk neutral then wages should be tied only to the aggregate price level (with $\epsilon=1$ ) and not to the other forces. If firms are risk averse, in theory wages should be tied to all of the other forces. However, small values of the elasticity of the firm's total revenues with respect to

in these conditional inferences for a given change in prices depends on the "information content" of aggregate prices. Other things equal, the higher the coefficient of variation of aggregate price shocks, the lower is this information content and thus the closer would be the elasticity of indexing to unity. We are grateful to the referee for calling this point to our attention.

${ }^{15}$ See Ehrenberg et al. (1982, app. A). Note further that if $A$ is also less than zero, so that indexing is less than complete, this implies that increased residual uncertainty reduces the extent of indexing. This apparently is a hypothesis that Estenson (1981) and Hendricks and Kahn (1983) sought to test. 
its output $(\psi)$; of the elasticity of its output with respect to other inputs $(\beta)$; and of the elasticities of output, demand, and input prices with respect to the random shocks will reduce the extent to which wages are tied to the other forces (see Ehrenberg et al. 1982, sec. 2). These factors, in addition to the ones we have described above, may explain why wages are typically not indexed to anything other than the aggregate price level.

\section{The Decision to Index}

As noted above, in recent years approximately $60 \%$ of all unionized workers covered by major collective bargaining agreements were also covered by COLA provisions. It would be only a coincidence if the optimal degree of wage indexation implied by (9) was zero for $40 \%$ of unionized employees. What factors are responsible then for such a large number of workers who have contracts that are not indexed at all?

The answer hinges on the possibility that there may be fixed real costs per worker of negotiating or administrating indexing clauses that must be borne either by the union or the employer. These costs may arise from a number of factors. For example, if a contract is indexed, union leaders may not receive "credit" from their members for the periodic nominal wage increases that automatically arise due to inflation. As a result, to maintain their political positions in the union, union leaders may push during contract negotiations for additional periodic noncontingent money wage increases; this may make it more difficult to reach a contract settlement.

To take another example, in a world of heterogeneous workers of differing skill levels, employers would like to have the flexibility to alter relative wages in response to external shortages or surpluses of workers in particular skill classes. Cost-of-living provisions, however, typically are specified as a given percentage increase in wages for each percentage increase in prices, or as a given absolute increase in wages for each percentage-point increase in prices. The former scheme rigidly preserves relative wage rates, while the latter causes skill differentials to be compressed. In either case, the employer loses the ability to alter relative wages during the period covered by the contract, and this reduces his willingness to agree to COLA provisions.

Suppose that we can represent these fixed real costs per worker of having an indexed contract by $c_{i}$. Indexing, of course, yields risk-sharing benefits to both employer and employees. The monetary value of these benefits is the total amount in real terms that both parties would be willing to pay to have wages indexed. One can show that this real benefit per worker less the real cost per worker of having an indexed contract is approximately equal to

$$
B=\frac{1}{2} \bar{w} \phi_{p}^{2} \epsilon^{2}\left(S-\bar{w} \underset{e}{N} V^{\prime \prime} / \underset{e}{E} V^{\prime}\right)-c_{i},
$$


where $\bar{w}=w(\bar{p}) / \bar{p}, \pi=\pi(\bar{p}) / \bar{p}, \epsilon$ is evaluated at $\bar{p}, S$ is evaluated at $\bar{w}$, and $V^{\prime}$ and $V^{\prime \prime}$ are evaluated at $\bar{\pi}$ (Ehrenberg et al. 1982, app. B).

While in general one cannot observe the continuous variable $B$, one can observe whether a contract contains a COLA, and it is reasonable to postulate in empirical implementations that

$$
\begin{aligned}
\hat{B} & =1 & & \text { if } B+v>0 \\
& =0 & & \text { otherwise. }
\end{aligned}
$$

Here $\hat{B}$ equals 1 if a contract has a COLA, zero otherwise; and $v$ is a random variable that summarizes all other unobservable forces that may influence COLA coverage.

From (11) and (12) it is straightforward to see how various forces influence the probability of a COLA's existing; these are summarized in table 1 . First, note that $a, b, \eta$, and $\beta$ influence $B$ only through $\epsilon$; thus their effect on the probability of observing a COLA is the same as their effect on the degree of indexing, given that indexing occurs and is positive. Second, one can show that the more risk averse workers are the greater the gain from indexing to them and thus the more likely one will observe an indexed contract. Third, while the expected rate of inflation has no effect on the probability of indexing, given that workers are risk averse, the more uncertain inflation is the greater is the gain to them of indexing and thus the greater is the likelihood of indexing. Fourth, an increase in the costs of having an indexed contract obviously reduces the probability of having such a contract. ${ }^{16}$ Finally, if one additionally assumes that $a$, $b, \eta, \beta, A, R$, and $S$ are constants and that the extent of employer risk aversion just equals that of employee risk aversion $(R=S)$, then an increase in residual uncertainty increases the probability of observing indexed contracts.

In the main, then, the same variables that affect the degree of indexing, if it occurs, also influence the probability of indexing. However, as table 1 indicates, in several cases the effect of a variable on the former may be different from its effect on the latter, and one variable, the coefficient of variation of expected inflation, influences only the latter.

\section{A 2-Period Model, Deferred Payments, and the Relationship between Contract Length and COLA Generosity}

The models discussed in the previous two sections are not structured in a way that enables us to address a number of issues. These include, What determines the length of collective bargaining agreements? How do

${ }^{16}$ The effect of these costs on the degree of indexing, if it occurs, is ambiguous and depends on the distribution of the costs between the workers and the firm, among other things. 
COLA provisions vary with contract duration? What determines the size of deferred wage increases that are not contingent on the price level in multiperiod contracts? Is there a trade-off between deferred increases and COLA provisions? To answer these questions one must move to a multiperiod model. We do so in this and the following section.

We consider, for simplicity, a 2-period model in which neither firms nor workers can borrow or lend. Let a subscript 1 (2) denote period 1 (2). Suppose first, that the workers' and the firm's utility functions both exhibit equal constant relative risk aversion $(S)$ and can be written respectively as

$$
\begin{aligned}
& U=U\left(w_{1} / p_{1}\right)+\rho U\left(w_{2} / p_{2}\right), \\
& V=V\left(\pi_{1} / p_{1}\right)+\rho V\left(\pi_{2} / p_{2}\right),
\end{aligned}
$$

where $\rho(>0)$ is a discount factor common to both workers and firms.

Suppose, also, that the firm's production function can be written as a Cobb-Douglas function

$$
Q_{1}=L_{1}^{\alpha} X_{1}^{\beta} e_{11}, \quad Q_{2}=L_{2}^{\alpha} X_{2}^{\beta} t_{1} e_{12},
$$

where $t_{1} \geqslant 0$ in period 2. Values of $t_{1}$ greater than unity indicate positive expected rates of productivity growth in this formulation.

Suppose next that the inverse demand functions and the input price functions are of constant-elasticity type and are given, respectively, by

$$
q_{1}=p_{1} Q_{1}^{-1 / n} \hat{p}_{1}^{a} e_{21}, \quad q_{2}=p_{2} Q_{2}^{-1 / n} \hat{p}_{1}^{\gamma a} \hat{p}_{2}^{a} t_{2} e_{22}
$$

and

$$
z_{1}=p_{1} \hat{p}_{1}^{b} e_{31}, \quad z_{2}=p_{2} \hat{p}_{1}^{\delta b} \hat{p}_{2}^{b} t_{3} e_{32} .
$$

Note that this specification allows both the demand function and input price schedules to change between periods and the effects of unanticipated inflation to persist over time, so that unanticipated inflation in period 1 may affect the demand curve and other input prices in period 2.

Specifically, here $\gamma(\delta)$ is the degree of serial correlation in the effect of unanticipated inflation on the demand function (input prices). If $\gamma(\delta)$ equals zero, unanticipated inflation in period 1 has no effect on the demand curve (input prices) in period 2. In contrast, if $\gamma(\delta)$ equals unity then unanticipated inflation in period 1 has the same effect on demand (input prices) in period 2 as does unanticipated inflation in period 2. The expected growth between periods in real demand is given, in the absence of any unanticipated inflation, by $t_{2}$ and the expected growth in input prices is similarly given by $t_{3}$. While the vector-of-error terms $e_{1}=$ 
$\left(e_{11}, e_{21}, e_{31}\right)$ and $e_{2}=\left(e_{12}, e_{22}, e_{32}\right)$ are assumed to be independent of the realized values of $p_{1}$ and $p_{2}$, they are not required to be independent of each other.

Finally, suppose that the wage that will prevail in the second period of the contract can be written as

$$
w_{2}=w_{1} y(\tilde{p}),
$$

where $w_{1}$ is the wage that prevails ex post in period $1, \tilde{p}$ equal to $p_{2} / p_{1}$ is the actual relative increase in the price level in the second period, and $y(\tilde{p})$ is the multiplier that translates the wage in period 1 into the wage in period 2. We assume that the realization of $\tilde{p}$ is independent of the realization of $p_{1}$ and that its expected value (the expected inflation rate in period 2) is $\bar{p}$, the same expected rate as in period 1. It is straightforward to see that the deferred wage change, as a percentage of the wage that prevails in period 1 , is given by $D-1$ where

$$
D=y(1) .
$$

When $\mathrm{D}$ is greater than (less than) unity a deferred increase (decrease) is called for in the contract. ${ }^{17}$

As before, the firm will always choose the variable inputs in each period to maximize the profits in that period and, given that this is done, all contracts that optimally share inflation risks can be obtained by choosing indexing schemes $w_{1}\left(p_{1}\right)$ and $y(\tilde{p})$ to maximize

$$
\begin{aligned}
£= & \underset{p_{1}}{\mathrm{E}} U\left(\frac{w_{1}}{p_{1}}\right)+\underset{p_{1}, \tilde{p}}{E} \rho U\left(\frac{w_{2}}{p_{2}}\right) \\
& +\lambda\left[\underset{p_{1}, e_{1}}{E} V\left(\frac{\pi_{1}}{p_{1}}\right)+\underset{p_{1}, \tilde{p}, e_{2}}{E} \rho V\left(\frac{\pi_{2}}{p_{2}}\right)\right] .
\end{aligned}
$$

It is tedious but straightforward to show that given the assumptions we have made, the magnitude of the deferred payment and the formulas for the optimal degree of wage indexing in the 2 periods are given by (Ehrenberg et al. 1982, sec. 4, app. C) ${ }^{18}$

$$
D=t \bar{p}^{-A}
$$

${ }^{17}$ Note that the definitions following eq. (18) require that the deferred increase be specified as a percentage of the wage that actually prevails in period 1 . This assumption is made for analytic convenience; one could also specify the deferred increase as an absolute amount.

${ }_{18}$ The formula is more complex for $p_{1} \neq \bar{p}$ in (21a). 


$$
\begin{gathered}
\epsilon_{1}=1+\left[\left(A+k A^{*}\right) /(1+k)\right] \text { for } p_{1}=\bar{p} \\
\epsilon_{2}=1+A,
\end{gathered}
$$

where

$$
A^{*}=\frac{a \gamma-b \delta \psi \beta}{1-\psi \beta}
$$

is the now constant elasticity of the real value added in period 2 with respect to the increase in the aggregate price level in the previous period,

$$
t=\left(t_{1}^{\psi} t_{2} t_{3}^{-\psi \beta}\right)^{1 /(1-\psi \beta)}
$$

is the expected growth in real value added when unanticipated inflation is zero in both periods, and

$$
k=\rho D^{1-s} \underset{\tilde{p}}{E} \tilde{p}^{A(1-s)}
$$

is the common, for workers and the firm, ratio of the expected marginal utility in period 1 from an increase in the wage in period 1 to the expected marginal utility in period 2 of an increase in the wage in period 1, when the rate of inflation in period 1 equals its expected value.

Equations (20) and (21a, b) immediately highlight a number of points. First, with the additional assumptions we have made in this section, the formula for the optimal degree of indexing in the 1-period model becomes identical to the formula for the optimal degree of indexing in the second period. ${ }^{19}$ Second, the deferred increase $D$ is proportional to the expected growth in real value added which the firm faces $(t)$ when unanticipated inflation is zero in both periods. While the expected rate of productivity growth $\left(t_{1}\right)$ influences this variable, so does the expected growth in demand $\left(t_{2}\right)$ and the expected growth in other input prices $\left(t_{3}\right)$. Third, unless the elasticity of real value added with respect to the increase in the price level in the same period $(A)$ is zero, the expected inflation rate influences the size of the deferred increase, with higher expected inflation rates leading to lower (higher) deferred increases if $A$ is greater (less) than zero. Moreover, any parameter that influences $A(a, b, \eta, \beta)$ will have opposite effects on the size of the deferred increase and on the degree of wage indexing in the second period. There is, then, a trade-off between COLA provisions and deferred wage increases.

What about the extent of wage indexing in the first period of the 2-period contract? Is it larger or smaller than the extent of indexing that

${ }^{19}$ That is, eq. (9) would reduce to (21b). 
would prevail in a 1-period contract, $(1+A)$ ? Equation (21) makes clear that the degree of indexing is larger in the first period of the 2-period contract than it is in the 1-period contract (recall the latter equals the degree of indexing in the second period of the 2-period contract) only if $A$ is less than $A^{*}$. The latter requires that $a \gamma-b \delta \psi \beta>a-b \psi \beta$.

Is this likely to occur? While no general theoretical statements can be made, we can consider two special cases. First, suppose that $b$ equals zero, so that unanticipated inflation does not influence input prices. If the degree of indexation in period 2 is less than complete $\left(\epsilon_{2}<1\right)$, which is typically the case, then $A$ and hence $a$ will be less than zero. In this case, the inequality will be satisfied as long as $\gamma<1$. That is, the extent of indexing will be greater during the first period of the 2-period model as long as the effect of unanticipated inflation on the firm's demand curve depreciates over time $(\gamma<1){ }^{20}$

Second, suppose that $b$ is not equal to zero but that the effect of unanticipated inflation on the demand and input price curves depreciates at the same rate $(\gamma=\delta)$. In this case, again as long as indexation is less than complete, so that $A$ and $a-b \psi \beta$ are both less than zero, it follows that if $\gamma$ is less than unity the extent of indexation will again be greater during the first period of the 2-period contract.

These special cases suggest that a reasonable hypothesis to test empirically is that as long as the observed extent of indexing is less than unity in the second period of a 2-period contract, the extent of indexing will be higher in the first period. Since the former equals the extent of indexing in the 1-period contract, on average the extent of indexing will be higher in the 2-period contract. Put more generally, one might expect to observe contracts of longer durations having more generous COLA provisions. Since the same factors that influence the generosity of a COLA also influence the probability of COLA coverage (see Sec. III), one should expect the incidence of COLAs to increase with contract length. In fact, this occurs. ${ }^{21}$

\section{The Optimum Duration of Labor Contracts}

In determining the optimal duration of a collective bargaining agreement, the parties to the agreement must consider the benefits and costs

${ }^{20}$ If $a$ equals 0 , and $\epsilon_{2}<1$, one similarly can show that $\delta<1$ is required to get the same result.

${ }^{21}$ For example, Douty (1981) reports that in $1975,3.2 \%$ of all contracts with a duration of 1 year, $14.8 \%$ of all contracts with a duration of 2 years, and $50 \%$ of all contracts with a duration of 3 years contained a COLA (these figures refer to major collective bargaining agreements only). Note that it may also be reasonable to assume that the effect of within-period unanticipated inflation on demand and input prices is closer to zero in the second period than in the first. If this is the case, it provides another reason why the degree of indexing is closer to complete in long-term contracts. 
of contracts of different lengths. ${ }^{22}$ For expository purposes we shall continue to contrast 1- and 2-period contracts in the context of our simple model.

Given the form of equation (17), which we believe to be a reasonable approximation to many actual contracts, there is inefficient risk sharing in the 2-period contract. Specifically, because inflation in the first period $\left(p_{1}\right)$ can affect wages in the second period $\left(w_{2}\right)$ only through its effect on wages in the first period $\left(w_{1}\right)$, inflation risks are generally not shared efficiently in the 2-period contract. A sequence of two 1-period contracts with equal degrees of wage indexing within each period can be shown to be preferable to the 2-period contract from a risk-sharing perspective.

The sequence of two 1-period contracts has costs as well as benefits, however. These costs are of two types. First, there are costs to the employer and the union of conducting collective bargaining negotiations. These are the explicit and implicit resource costs of the negotiations process including, but not limited to, the time diverted from production, contract administration, and planning activities. Although lost output due to strikes is an example of such costs, we emphasize that they may be substantial even in the absence of a strike or threat of strike. Multiperiod contracts obviously reduce the frequency with which these costs are incurred. Second, since the two 1-period contracts are negotiated sequentially, there is invariably some uncertainty, as of period one, about what the terms of the second contract will be, and this uncertainty will generate costs for the parties if they are risk averse. Multiperiod contracts reduce this form of uncertainty also.

The choice of contract duration obviously involves a weighting of the loss from inefficient sharing of inflation risks, if a multiperiod contract is chosen, against the loss from additional bargaining costs and the uncertainty about the second-period contract, if two 1-period contracts are chosen. It is again straightforward to show that an increase either in the cost of collective bargaining or in the uncertainty in the first of two 1period contracts, caused by not knowing what the wage bargain will be in the second period, will increase the probability of a 2-period contract. On the other hand, since the expected inflation rate $(\bar{p})$ does not affect the expected utility from contracts of either length, it will not affect the choice of length. The serial correlation in the effects of unanticipated inflation on demand $(\gamma)$ and other input prices $(\delta)$ can also be shown to influence contract duration in a predictable manner that depends on the magnitudes of several other parameters in the model. Finally, while the remaining parameters in the model all influence the optimum duration

${ }^{22}$ See Ehrenberg et al. (1982), sec. 7, for a more extended discussion of the question of contract duration including the presentation of formal models. 
of labor contracts, without further restrictive assumptions one cannot obtain unambiguous implications about their effects. ${ }^{23}$

\section{Temporary Layoffs and COLA Coverage}

In the final theoretical section of our longer paper, we return to a 1-period model with indexing of wages, but we allow employment to be variable across states of the world. This section stresses that temporary layoffs and the extent of indexing are simultaneously determined and highlights the role played by several parameters of the unemployment insurance (UI) system. ${ }^{24}$ To capture what we consider to be the essential features of the UI system, nominal UI benefits that laid-off unemployed workers receive are specified not to be contingent on the realized price level during the period, and employers' nominal unemployment insurance tax payments are specified to be imperfectly experience rated. As in the previous models, employers seek to maximize their expected utility from profits and the union seeks to maximize the expected utility of its representative member. The latter, in each state of the world, is now a weighted average of the worker's utility when he is employed and his utility when he is laid off, where the weights reflect the probability of being on layoff in the state of the world.

In such a framework, contracts that provide for efficient sharing of inflation risk will require that both the wage rate and the employment level depend on the aggregate price level. ${ }^{25}$ Given the model of our longer paper, it is straightforward to derive employment $(L[p])$ and wage $(w[p])$ schedules and to see how they depend on parameters of the UI system (see Ehrenberg et al. [1982] for details).

Our key results are, first, an increase in UI benefits or a decrease in the extent of experience rating will lead to increased layoffs in each state

${ }^{23}$ An alternative approach to the determination of optimal contract duration is found in Gray (1978). There, contract length is determined by the fact that the conditional inferences of the observed real variables, given aggregate prices, becomes less and less precise as time goes on. At some point, in this framework, the cost of renegotiation is just equal to the expected benefit from being able to adjust wages back to their "full-information" levels. Because of our specification of the joint distribution of aggregate and relative price shocks (see n. 14), we have ignored this aspect of the contract length trade-off.

${ }^{24}$ Feldstein (1976) has stressed the effect of UI system parameters on temporary layoffs, but he does so in the context of a model in which both workers and firms are risk neutral, so that the degree of indexation is indeterminate. See also Baily (1977).

${ }^{25}$ As the referee has pointed out, it is hard to think of empirical analogues to the employment function our model produces that are explicitly contingent on the aggregate price level. Why we observe wage escalators but not employment escalators in actual labor contracts, is an open question. 
of the world. Second, if indexing is less than complete $(\epsilon<1)$, an increase in experience rating will lead to an increase in the extent of wage indexing. Third, if indexing is less than complete and experience rating is "sufficiently imperfect," an increase in UI benefits will decrease the extent of wage indexing. Although we have not formally modeled the forces that influence the decision to have an indexed contract in this variable employment model, our discussion in Section III suggests that the effects of the UI parameters on the probability of observing an indexed contract are likely to be of the same sign as their effects on the extent of indexing, given that indexing exists.

\section{Empirical Analyses: Two-Digit Manufacturing Industry Data}

This section and the following one provide initial empirical tests of a few of the hypotheses generated by our models. Here, we use data at the two-digit manufacturing industry level and focus on the determinants both of the industry layoff rate and of the percentage of workers covered by major collective bargaining agreements who are also covered by a COLA provision. In the next, we use individual collective bargaining agreement data and analyze the determinants of COLA coverage, characteristics of COLAs (when they exist), and the duration of collective bargaining agreements.

Our approach in this section is to estimate equations of the form

$$
F_{i t}=\sum_{j=1}^{13} \theta_{j 1} v_{j i t}+\sum_{k=1}^{4} \phi_{k 1} a_{k i t}+\Gamma_{1} U I_{i}+\sum_{m=1}^{3} D_{m 1} d_{i t}+u_{1 i t}
$$

and

$$
l_{i t}=\sum_{j=1}^{13} \theta_{j 2} v_{j i t}+\sum_{k=1}^{4} \phi_{k 2} a_{k i t}+\Gamma_{2} U I_{i}+\sum_{m=1}^{3} D_{m 2} d_{i t}+u_{2 i t} .
$$

Here $F_{i t}$ represents the fraction of the workers covered by major collective bargaining agreements in industry $i$ in year $t$ who are also covered by COLA provisions, and $l_{i t}$ represents the 3 -year average layoff rate in industry $i$ in year $t$. The $v$ 's are variables that reflect personal characteristics of unionized workers in the industry and the industry bargaining structure, the $a$ 's are estimates of several demand-related variables (elasticity of industry demand with respect to unanticipated inflation $\left[a_{1}=a\right]$, serial correlation in the effect of unanticipated inflation on industry demand $\left[a_{2}=\gamma\right]$, the expected growth of demand $\left[a_{3}=t\right]$, and pure random variations in demand and productivity $\left[a_{4}=\phi_{v}\right]$ ), UI represents the average net unemployment insurance replacement rate in the industrythe average weekly UI benefits divided by the average weekly net (after 
tax) loss of income incurred by laid-off unemployed workers in the industry, the $d$ 's are industry and year dummy variables, the $u$ 's random variables, and $\theta, \phi, \Gamma$, and $D$ parameters to be estimated. A more complete description of the data, including its sources, is found in Ehrenberg et al. (1982, app. D), and a complete list of the explanatory variables is found here in table 2.

Several comments should be made about this specification. First, we use data pooled across 3 years, Since many labor contracts are long-term, we do not use data for adjacent years, which would make it possible for the same contract to influence the industry "outcome" variables in more than one year. Rather, we use data for 1975, 1978, and 1981.

Second, it is difficult to make unambiguous predictions about the expected signs of many of the $v$ variables, because they do not always correspond neatly in a one-to-one fashion with variables from the theoretical models. For example, a bargaining structure variable, such as the number of unions in the industry, may serve as a proxy for the costs of having an indexed contract, the costs of concluding a collective bargaining agreement, and the share of the pie that the employer wins $(\lambda)$. Similarly, while personal characteristics of unionized workers may reflect employee relative risk aversion $(S)$, some may also influence the costs of conducting negotiations, the costs of indexed contracts, and, indeed, employer and employee demands for long-term employment relationships. As such, we will not discuss these variables' coefficients below.

Third, the estimated parameters of the demand function were obtained as follows. Using quarterly data on the Consumer Price Index $\left(P_{t}\right)$ from 1970 to 1978 , an expected CPI series $(E[P(t)])$ was generated using a fourth-order autoregressive model. For each two-digit manufacturing industry, equations of the form

$$
\log \left(S_{i t} / P_{t}\right)=h_{11}+b_{12} \log \left[P_{t} / E\left(P_{t}\right)\right]+h_{13} T+u_{1 t}
$$

and

$$
\begin{aligned}
\log \left(S_{i t} / P_{t}\right)=h_{21} & +h_{22} \log \left[P_{t} / E\left(P_{t}\right)\right] \\
& +h_{23} \log \left(S_{i t-1} / P_{t-1}\right)+h_{24} T+u_{2 t}
\end{aligned}
$$

were then estimated using quarterly data from 1971 to 1978 , where $S_{i t}$ is the value of shipments in industry $i$ in year $t, T$ is a time-trend term that is incremented quarterly, and the $u$ 's are random error terms. When equation (24) is used, which allows for no serial correlation in the effects of unanticipated inflation on demand, $a_{1}, a_{3}$, and $a_{4}$ are estimated, respectively, by $\hat{b}_{12}, \hat{b}_{13}$, and $\hat{\sigma}_{u 1}^{2}$. Similarly, when equation $(25)$ is used, 
which allows for serial correlation, one can show that $a_{1}, a_{2}, a_{3}$, and $a_{4}$ are given, respectively, by $\hat{h}_{22}, \hat{b}_{23}, \hat{b}_{24} /\left(1-\hat{b}_{23}\right)$, and $\hat{\sigma}_{u 2}^{2}{ }^{26}$

Fourth, a key explanatory variable is the average unemployment insurance net replacement rate $(U I)$ - the average weekly UI benefits divided by the average weekly net (after tax) loss of income by laid-off unemployed workers in the industry. These data are obtained from a large scale microsimulation model of the unemployment insurance system built by the Urban Institute, and are based on data from the Survey of Income and Education. ${ }^{27}$

Finally, dummy variables that indicate the year of the data and whether the industry is in durable manufacturing are also included in the model. The former are meant to control for variations in expected inflation and in the coefficient of variation of expected inflation over time. The latter is another proxy for negotiations costs, the elasticity of the firm's demand curve with respect to its own price, and the costs of indexed contracts.

Estimates of variants of equations (24) and (25) are found in tables 2 and 3; where the dependent variables are, respectively, the fraction of the workers under major collective bargaining agreements who are covered by a COLA and the 3-year average of the industry layoff rate. ${ }^{28}$ Quite strikingly, a number of key implications of the models are confirmed.

First, as suggested in Section VI, higher UI replacement rates in an industry are associated with a lower probability of observing an indexed contract and a higher level of industry layoffs. These results support the notion that cost of living indexing and the level of temporary layoffs are simultaneously determined. ${ }^{29}$

${ }^{26}$ Suppose that

$$
\left(S_{i t} / P_{t}\right)=a_{0} \prod_{r=0}^{\infty}\left[\left(P_{t-i} / E\left(P_{t-i}\right)\right]^{a_{1} a_{2}^{r}} e^{a_{3} t} e^{u_{i t}},\right.
$$

where $a_{1}$ represents the effect of unanticipated inflation on demand, $a_{2}$ the serial correlation in the effects of unanticipated inflation and $a_{3}$ the expected growth in demand. Taking logs of the equation, lagging it one period and multiplying the lagged equation by $a_{2}$, and then subtracting this from the unlagged equation, the result in the text immediately follows. We should caution here that these parameters may actually represent parameters of the real value-added function, not parameters of the demand curve. However, since the implications are essentially the same, for expository convenience we continue in the text to refer to them as parameters of the demand function.

${ }^{27}$ See Vroman (1980) for a description of the model and data. We are grateful to him for generously providing us with these data.

${ }^{28}$ Virtually identical results to those in table 2 were obtained when the fraction of agreements containing COLAs was used as a dependent variable.

${ }^{29} \mathrm{~A}$ referee suggested the possibility that UI replacement rates are negatively correlated with industry wage levels and hence the UI coefficient may simply indicate that COLAs are more frequent in higher wage industries. Inclusion of the industry wage as an additional explanatory variable, however, did not alter the sign or significance of the UI variables in tables 2 and 3. 
Table 2

Determinants of Fraction of Workers Covered by a COLA, by Two-Digit Manufacturing: 1975, 1978, 1981

\begin{tabular}{|c|c|c|c|c|c|c|c|}
\hline & (1) & (2) & (3) & (4) & (5) & (6) & (7) \\
\hline$v 1$ & $\begin{array}{r}-.117 \\
(2.9)\end{array}$ & $\begin{array}{r}-.054 \\
(1.8)\end{array}$ & $\begin{array}{r}-.056 \\
(1.5)\end{array}$ & $\begin{array}{r}-.039 \\
(1.2)\end{array}$ & $\begin{array}{c}.008 \\
(.1)\end{array}$ & $\begin{array}{r}.014 \\
(.3)\end{array}$ & $\begin{array}{l}.142 \\
(1.6)\end{array}$ \\
\hline$v 2$ & $\begin{array}{r}-.008 \\
(1.5)\end{array}$ & $\begin{array}{r}-.002 \\
(.4)\end{array}$ & $\begin{array}{r}-.017 \\
(3.3)\end{array}$ & $\begin{array}{r}-.007 \\
(1.4)\end{array}$ & $\begin{array}{r}-.012 \\
(2.2)\end{array}$ & $\begin{array}{r}-.007 \\
(1.6)\end{array}$ & $\begin{array}{r}-.009 \\
(1.1)\end{array}$ \\
\hline$v 3$ & $\begin{array}{l}.087 \\
(1.7)\end{array}$ & $\begin{array}{r}.040 \\
(.9)\end{array}$ & $\begin{array}{l}.268 \\
(4.7)\end{array}$ & $\begin{array}{l}.141 \\
(2.7)\end{array}$ & $\begin{array}{l}.222 \\
(3.6)\end{array}$ & $\begin{array}{l}.133 \\
(2.5)\end{array}$ & $\begin{array}{l}.144 \\
(1.8)\end{array}$ \\
\hline$v 4$ & $\begin{array}{r}-.001 \\
(.1)\end{array}$ & $\begin{array}{r}-.008 \\
(1.1)\end{array}$ & $\begin{array}{r}-.007 \\
(.8)\end{array}$ & $\begin{array}{r}-.011 \\
(1.5)\end{array}$ & $\begin{array}{r}-.011 \\
(1.2)\end{array}$ & $\begin{array}{r}-.011 \\
(1.5)\end{array}$ & $\begin{array}{r}-.012 \\
(1.3)\end{array}$ \\
\hline$v 5$ & $\begin{array}{l}.559 \\
(1.5)\end{array}$ & $\begin{array}{l}.769 \\
(2.9)\end{array}$ & $\begin{array}{l}.440 \\
(1.4)\end{array}$ & $\begin{array}{l}.696 \\
(2.6)\end{array}$ & $\begin{array}{r}.220 \\
(.7)\end{array}$ & $\begin{array}{l}.540 \\
(1.8)\end{array}$ & $\begin{array}{r}.263 \\
(.6)\end{array}$ \\
\hline$v 6$ & $\begin{array}{r}4.315 \\
(2.9)\end{array}$ & $\begin{array}{r}5.123 \\
(4.3)\end{array}$ & $\begin{array}{r}.422 \\
(.3)\end{array}$ & $\begin{array}{r}2.795 \\
(2.0)\end{array}$ & $\begin{array}{r}-.192 \\
(.1)\end{array}$ & $\begin{array}{r}1.980 \\
(1.2)\end{array}$ & $\begin{array}{r}.290 \\
(.1)\end{array}$ \\
\hline$v 7$ & $\begin{array}{l}.048 \\
(1.8)\end{array}$ & $\begin{array}{l}.114 \\
(4.5)\end{array}$ & $\begin{array}{l}.031 \\
(1.3)\end{array}$ & $\begin{array}{l}.098 \\
(3.9)\end{array}$ & $\begin{array}{l}.054 \\
(2.0)\end{array}$ & $\begin{array}{l}.100 \\
(4.0)\end{array}$ & $\begin{array}{l}.089 \\
(2.4)\end{array}$ \\
\hline$v 8$ & $\begin{array}{r}-6.357 \\
(3.5)\end{array}$ & $\begin{array}{r}-4.325 \\
(3.1)\end{array}$ & $\begin{array}{r}-6.127 \\
(4.2)\end{array}$ & $\begin{array}{r}-5.010 \\
(3.7)\end{array}$ & $\begin{array}{r}-3.789 \\
(1.8)\end{array}$ & $\begin{array}{r}-3.524 \\
(1.9)\end{array}$ & $\begin{array}{r}-1.255 \\
(.5)\end{array}$ \\
\hline$v 9$ & $\begin{array}{r}-1.983 \\
(1.1)\end{array}$ & $\begin{array}{r}-6.597 \\
(3.1)\end{array}$ & $\begin{array}{r}1.255 \\
(.7)\end{array}$ & $\begin{array}{r}-4.914 \\
(2.3)\end{array}$ & $\begin{array}{r}1.522 \\
(1.0)\end{array}$ & $\begin{array}{r}-3.432 \\
(1.4)\end{array}$ & $\begin{array}{r}-2.162 \\
(.7)\end{array}$ \\
\hline$v 10$ & $\begin{array}{r}-.933 \\
(1.7)\end{array}$ & $\begin{array}{r}-.146 \\
(.4)\end{array}$ & $\begin{array}{r}.152 \\
(.3)\end{array}$ & $\begin{array}{l}.524 \\
(1.2)\end{array}$ & $\begin{array}{l}.653 \\
(1.1)\end{array}$ & $\begin{array}{l}.685 \\
(1.5)\end{array}$ & $\begin{array}{r}1.072 \\
(1.9)\end{array}$ \\
\hline$v 11$ & $\begin{array}{r}.185 \\
(.1)\end{array}$ & $\begin{array}{r}.688 \\
(.7)\end{array}$ & $\begin{array}{r}-4.176 \\
(3.2)\end{array}$ & $\begin{array}{r}-2.172 \\
(1.6)\end{array}$ & $\begin{array}{r}-3.053 \\
(2.1)\end{array}$ & $\begin{array}{r}-1.634 \\
(1.1)\end{array}$ & $\begin{array}{r}-1.365 \\
(.7)\end{array}$ \\
\hline$v 12$ & $\begin{array}{l}.329 \\
(1.0)\end{array}$ & $\begin{array}{l}.360 \\
(1.2)\end{array}$ & $\begin{array}{l}.759 \\
(2.6)\end{array}$ & $\begin{array}{l}.732 \\
(2.3)\end{array}$ & $\begin{array}{l}.390 \\
(1.0)\end{array}$ & $\begin{array}{l}.442 \\
(1.1)\end{array}$ & $\begin{array}{r}.193 \\
(.4)\end{array}$ \\
\hline$v 13$ & $\begin{array}{r}1.187 \\
(1.2)\end{array}$ & $\begin{array}{r}1.091 \\
(1.2)\end{array}$ & $\begin{array}{r}-2.061 \\
(2.0)\end{array}$ & $\begin{array}{r}-1.084 \\
(1.0)\end{array}$ & $\begin{array}{r}-1.481 \\
(1.3)\end{array}$ & $\begin{array}{r}-.685 \\
(.6)\end{array}$ & $\begin{array}{r}-.607 \\
(.4)\end{array}$ \\
\hline$a_{1}$ & $\begin{array}{l}.078 \\
(2.6)\end{array}$ & $\begin{array}{l}.044 \\
(1.6)\end{array}$ & $\begin{array}{l}.065 \\
(2.6)\end{array}$ & $\begin{array}{l}.056 \\
(2.2)\end{array}$ & $\begin{array}{l}.031 \\
(1.0)\end{array}$ & $\begin{array}{l}.003 \\
(1.0)\end{array}$ & $\begin{array}{r}.000 \\
(.0)\end{array}$ \\
\hline$a_{2}$ & $\cdots$ & $\begin{array}{r}-.995 \\
(3.0)\end{array}$ & $\cdots$ & $\begin{array}{r}-.606 \\
(1.7)\end{array}$ & $\ldots$ & $\begin{array}{r}-.664 \\
(1.9)\end{array}$ & $\begin{array}{r}-.834 \\
(2.0)\end{array}$ \\
\hline$a_{3}$ & $\begin{array}{r}27.120 \\
(1.5)\end{array}$ & $\begin{array}{r}1.006 \\
(.7)\end{array}$ & $\begin{array}{r}33.506 \\
(2.2)\end{array}$ & $\begin{array}{r}1.891 \\
(1.3)\end{array}$ & $\begin{array}{r}10.794 \\
(.5)\end{array}$ & $\begin{array}{r}1.752 \\
(1.2)\end{array}$ & $\begin{array}{r}1.111 \\
(.6)\end{array}$ \\
\hline$a_{4}$ & $\begin{array}{r}-59.172 \\
(2.2)\end{array}$ & $\begin{array}{r}-5.914 \\
(.2)\end{array}$ & $\begin{array}{r}-75.091 \\
(3.3)\end{array}$ & $\begin{array}{r}-25.556 \\
(1.0)\end{array}$ & $\begin{array}{r}-43.323 \\
(1.4)\end{array}$ & $\begin{array}{r}-7.547 \\
(.2)\end{array}$ & $\begin{array}{r}1.144 \\
(.0)\end{array}$ \\
\hline$U I$ & $\ldots$ & $\ldots$ & $\ldots$ & $\ldots$ & $\begin{array}{r}-1.754 \\
(1.6)\end{array}$ & $\begin{array}{r}-1.226 \\
(1.2)\end{array}$ & $\begin{array}{r}-2.637 \\
(1.8)\end{array}$ \\
\hline D1 & $\cdots$ & $\ldots$ & $\begin{array}{l}.731 \\
(4.8)\end{array}$ & $\begin{array}{l}.413 \\
(2.8)\end{array}$ & $\begin{array}{l}724 \\
(4.9)\end{array}$ & $\begin{array}{l}.431 \\
(3.0)\end{array}$ & $\begin{array}{l}.435 \\
(2.5)\end{array}$ \\
\hline D2 & $\cdots$ & $\cdots$ & $\begin{array}{l}.066 \\
(1.1)\end{array}$ & $\begin{array}{l}.091 \\
(1.9)\end{array}$ & $\begin{array}{l}.099 \\
(1.6)\end{array}$ & $\begin{array}{l}.112 \\
(2.2)\end{array}$ & $\begin{array}{r}-.063 \\
(1.0)\end{array}$ \\
\hline D3 & $\cdots$ & $\cdots$ & $\begin{array}{l}.093 \\
(1.4)\end{array}$ & $\begin{array}{l}.085 \\
(1.6)\end{array}$ & $\begin{array}{l}.138 \\
(2.0)\end{array}$ & $\begin{array}{l}.127 \\
(2.0)\end{array}$ & $\ldots$ \\
\hline$L D$ & $\cdots$ & $\cdots$ & $\cdots$ & $\ldots$ & $\ldots$ & $\cdots$ & $\begin{array}{r}.121 \\
(.7)\end{array}$ \\
\hline$R^{2}$ & .771 & .872 & .870 & .904 & .869 & .908 & .945 \\
\hline$N$ & 60 & 60 & 60 & 60 & 60 & 60 & 40 \\
\hline
\end{tabular}

NOTE.-See app. D of Ehrenberg et al. (1982) for a description of data sources. Absolute value of $t$ statistics in parentheses. Variables as follows:

$v 1=3$-year average quit rate;

$v 2=$ number of unions in industry;

$v 3=$ percentage of unionized workers in industry;

$v 4=3$-year average profit rate;

$v 5=$ percentage of workers covered by multiemployer agreements in industry;

$v 6=$ percentage of income due to wage earnings of union member;

$v 7=$ mean age of union members;

$v 8=$ percentage of union members married;

$v 9=$ percentage of union members white

$v 10=$ percentage of union members male;

$v 11=$ percentage of union members residing in SMSAs;

$v 12=$ mean schooling level of union members

$v 13=$ mean number of children in married union members' families;

$D 1=1$ if durable goods industry, 0 otherwise;

$D 2=1$ if 1981,0 otherwise;

$D 3=1$ if 1978,0 otherwise

$U I=$ average UI net replacement rate $=$ average weekly UI benefits/average weekly net (after tax) loss of income by laid-off unemployed workers in the industry;

$L D=$ lagged (3 years) dependent variable;

$a_{1}=$ estimate of elasticity of industry demand with respect to unanticipated inflation;

$a_{2}=$ estimate of serial correlation in effect of unanticipated inflation on industry demand;

$a_{3}=$ estimate of expected growth in demand;

$a_{4}=$ estimate of pure random variation in demand, productivity, and other input prices. 
Second, an increase in the elasticity of the demand curve with respect to unanticipated inflation $\left(a_{1}\right)$ appears to be associated with an increase in the probability of an indexed contract, as suggested in Section III. Furthermore, the effect of an increase in the serial correlation of unanticipated inflation on the probability of an indexed contract can be shown, from equation (21), to be the same sign as the elasticity of the demand curve with respect to unanticipated inflation. If indexing is less than complete $(\epsilon<1)$, which is typical, ceteris paribus, this elasticity will tend

Table 3

Determinants of the Industry Layoff Rate (3-Year Average), by Two-Digit Manufacturing Industry: 1975, 1978, 1981

\begin{tabular}{|c|c|c|c|c|c|c|c|}
\hline & (1) & (2) & (3) & (4) & (5) & (6) & (7) \\
\hline$v 1$ & $\begin{array}{l}.006 \\
(6.3)\end{array}$ & $\begin{array}{l}.006 \\
(7.5)\end{array}$ & $\begin{array}{l}.004 \\
(4.9)\end{array}$ & $\begin{array}{l}.004 \\
(5.7)\end{array}$ & $\begin{array}{l}.003 \\
(2.2)\end{array}$ & $\begin{array}{c}.001 \\
(.8)\end{array}$ & $\begin{array}{c}.001 \\
(.0)\end{array}$ \\
\hline$v 2$ & $\begin{array}{r}.000 \\
(.6)\end{array}$ & $\begin{array}{r}-.000 \\
(.9)\end{array}$ & $\begin{array}{l}.000 \\
(1.5)\end{array}$ & $\begin{array}{r}.000 \\
(.9)\end{array}$ & $\begin{array}{r}.000 \\
(.6)\end{array}$ & $\begin{array}{l}.000 \\
(1.4)\end{array}$ & $\begin{array}{l}.000 \\
(1.6)\end{array}$ \\
\hline$v 3$ & $\begin{array}{l}.004 \\
(3.1)\end{array}$ & $\begin{array}{l}.005 \\
(4.2)\end{array}$ & $\begin{array}{l}.003 \\
(2.6)\end{array}$ & $\begin{array}{l}.002 \\
(1.8)\end{array}$ & $\begin{array}{l}.004 \\
(3.0)\end{array}$ & $\begin{array}{l}.003 \\
(2.5)\end{array}$ & $\begin{array}{l}.003 \\
(1.9)\end{array}$ \\
\hline$v 4$ & $\begin{array}{r}-.001 \\
(.4)\end{array}$ & $\begin{array}{r}.000 \\
(.1)\end{array}$ & $\begin{array}{r}-.000 \\
(1.6)\end{array}$ & $\begin{array}{r}-.000 \\
(1.2)\end{array}$ & $\begin{array}{r}-.000 \\
(1.2)\end{array}$ & $\begin{array}{r}-.000 \\
(1.3)\end{array}$ & $\begin{array}{r}-.000 \\
(1.2)\end{array}$ \\
\hline$v 5$ & $\begin{array}{r}-.024 \\
(2.8)\end{array}$ & $\begin{array}{r}-.021 \\
(2.8)\end{array}$ & $\begin{array}{r}-.015 \\
(2.1)\end{array}$ & $\begin{array}{r}-.007 \\
(1.0)\end{array}$ & $\begin{array}{r}-.011 \\
(1.3)\end{array}$ & $\begin{array}{r}.004 \\
(.6)\end{array}$ & $\begin{array}{l}.011 \\
(1.1)\end{array}$ \\
\hline$v 6$ & $\begin{array}{r}-.028 \\
(.8)\end{array}$ & $\begin{array}{r}-.025 \\
(.7)\end{array}$ & $\begin{array}{r}-.030 \\
(.9)\end{array}$ & $\begin{array}{r}.026 \\
(.7)\end{array}$ & $\begin{array}{r}-.017 \\
(.5)\end{array}$ & $\begin{array}{l}.086 \\
(2.4)\end{array}$ & $\begin{array}{l}.127 \\
(2.4)\end{array}$ \\
\hline$v 7$ & $\begin{array}{r}-.000 \\
(.5)\end{array}$ & $\begin{array}{r}-.001 \\
(1.4)\end{array}$ & $\begin{array}{r}-.000 \\
(.3)\end{array}$ & $\begin{array}{r}-.000 \\
(.1)\end{array}$ & $\begin{array}{r}-.001 \\
(1.0)\end{array}$ & $\begin{array}{r}-.000 \\
(.4)\end{array}$ & $\begin{array}{r}.000 \\
(.4)\end{array}$ \\
\hline$v 8$ & $\begin{array}{r}-.002 \\
(.0)\end{array}$ & $\begin{array}{r}.022 \\
(.5)\end{array}$ & $\begin{array}{r}-.016 \\
(.5)\end{array}$ & $\begin{array}{r}-.014 \\
(.4)\end{array}$ & $\begin{array}{r}-.066 \\
(1.4)\end{array}$ & $\begin{array}{r}-.122 \\
(2.9)\end{array}$ & $\begin{array}{r}-.197 \\
(3.0)\end{array}$ \\
\hline$v 9$ & $\begin{array}{l}.215 \\
(5.2)\end{array}$ & $\begin{array}{l}.268 \\
(4.7)\end{array}$ & $\begin{array}{l}.189 \\
(5.0)\end{array}$ & $\begin{array}{l}.171 \\
(3.1)\end{array}$ & $\begin{array}{l}.184 \\
(4.9)\end{array}$ & $\begin{array}{l}.065 \\
(1.1)\end{array}$ & $\begin{array}{r}.043 \\
(.5)\end{array}$ \\
\hline$v 10$ & $\begin{array}{r}-.021 \\
(1.7)\end{array}$ & $\begin{array}{r}-.038 \\
(3.4)\end{array}$ & $\begin{array}{r}-.014 \\
(1.2)\end{array}$ & $\begin{array}{r}-.037 \\
(3.3)\end{array}$ & $\begin{array}{r}-.025 \\
(1.8)\end{array}$ & $\begin{array}{r}-.049 \\
(4.8)\end{array}$ & $\begin{array}{r}-.063 \\
(4.0)\end{array}$ \\
\hline$v 11$ & $\begin{array}{l}.042 \\
(1.5)\end{array}$ & $\begin{array}{l}.057 \\
(2.0)\end{array}$ & $\begin{array}{r}.023 \\
(.8)\end{array}$ & $\begin{array}{l}.074 \\
(2.0)\end{array}$ & $\begin{array}{r}-.000 \\
(.0)\end{array}$ & $\begin{array}{l}.035 \\
(1.0)\end{array}$ & $\begin{array}{r}.031 \\
(.7)\end{array}$ \\
\hline$v 12$ & $\begin{array}{r}-.025 \\
(3.2)\end{array}$ & $\begin{array}{r}-.031 \\
(3.6)\end{array}$ & $\begin{array}{r}-.020 \\
(3.0)\end{array}$ & $\begin{array}{r}-.026 \\
(3.1)\end{array}$ & $\begin{array}{r}-.012 \\
(1.4)\end{array}$ & $\begin{array}{r}-.005 \\
(.6)\end{array}$ & $\begin{array}{r}-.002 \\
(.1)\end{array}$ \\
\hline$v 13$ & $\begin{array}{l}.064 \\
(2.7)\end{array}$ & $\begin{array}{l}.083 \\
(3.3)\end{array}$ & $\begin{array}{l}.046 \\
(1.9)\end{array}$ & $\begin{array}{l}.091 \\
(3.0)\end{array}$ & $\begin{array}{l}.033 \\
(1.3)\end{array}$ & $\begin{array}{l}.062 \\
(2.3)\end{array}$ & $\begin{array}{l}.074 \\
(2.1)\end{array}$ \\
\hline$a_{1}$ & $\begin{array}{r}-.001 \\
(1.9)\end{array}$ & $\begin{array}{r}-.002 \\
(2.4)\end{array}$ & $\begin{array}{r}-.001 \\
(2.1)\end{array}$ & $\begin{array}{r}-.001 \\
(1.8)\end{array}$ & $\begin{array}{r}-.000 \\
(.6)\end{array}$ & $\begin{array}{r}.001 \\
(.9)\end{array}$ & $\begin{array}{l}.001 \\
(1.2)\end{array}$ \\
\hline$a_{2}$ & $\ldots$ & $\begin{array}{r}-.029 \\
(3.0)\end{array}$ & $\ldots$ & $\begin{array}{r}-.024 \\
(2.6)\end{array}$ & $\ldots$ & $\begin{array}{r}-.020 \\
(2.5)\end{array}$ & $\begin{array}{r}-.018 \\
(1.8)\end{array}$ \\
\hline$a_{3}$ & $\begin{array}{r}-.076 \\
(1.8)\end{array}$ & $\begin{array}{r}-.107 \\
(2.4)\end{array}$ & $\begin{array}{r}-.686 \\
(2.0)\end{array}$ & $\begin{array}{r}-.085 \\
(2.2)\end{array}$ & $\begin{array}{r}-.202 \\
(.4)\end{array}$ & $\begin{array}{r}-.075 \\
(2.2)\end{array}$ & $\begin{array}{r}-.085 \\
(1.9)\end{array}$ \\
\hline$a_{4}$ & $\begin{array}{r}1.106 \\
(1.7)\end{array}$ & $\begin{array}{r}.539 \\
(.6)\end{array}$ & $\begin{array}{l}.967 \\
(1.8)\end{array}$ & $\begin{array}{r}.566 \\
(.8)\end{array}$ & $\begin{array}{r}.291 \\
(.4)\end{array}$ & $\begin{array}{r}-.739 \\
(1.0)\end{array}$ & $\begin{array}{r}-.805 \\
(.7)\end{array}$ \\
\hline$U I$ & $\ldots$ & $\ldots$ & $\cdots$ & $\ldots$ & $\begin{array}{l}.037 \\
(1.4)\end{array}$ & $\begin{array}{l}.089 \\
(3.7)\end{array}$ & $\begin{array}{l}.124 \\
(2.9)\end{array}$ \\
\hline$D 1$ & $\ldots$ & $\ldots$ & $\begin{array}{r}.003 \\
(.9)\end{array}$ & $\begin{array}{r}-.004 \\
(1.0)\end{array}$ & $\begin{array}{r}.003 \\
(.9\end{array}$ & $\begin{array}{r}-.005 \\
(1.5)\end{array}$ & $\begin{array}{r}-.008 \\
(1.8)\end{array}$ \\
\hline D2 & $\ldots$ & $\ldots$ & $\begin{array}{r}-.001 \\
(.5)\end{array}$ & $\begin{array}{r}-.000 \\
(.3)\end{array}$ & $\begin{array}{r}-.001 \\
(.9)\end{array}$ & $\begin{array}{r}-.002 \\
(1.7)\end{array}$ & $\begin{array}{l}.005 \\
(2.1)\end{array}$ \\
\hline D3 & $\ldots$ & $\ldots$ & -.006 & -.006 & -.007 & -.009 & \\
\hline$L D$ & $\ldots$ & $\ldots$ & $\ldots$ & $\ldots$ & $\ldots$ & $\ldots$ & $\begin{array}{r}-.284 \\
(1.5)\end{array}$ \\
\hline $\begin{array}{l}R^{2} \\
N\end{array}$ & $\begin{array}{l}.749 \\
60\end{array}$ & $\begin{array}{l}.788 \\
60\end{array}$ & $\begin{array}{l}.857 \\
60\end{array}$ & $\begin{array}{l}.866 \\
60\end{array}$ & $\begin{array}{l}.860 \\
60\end{array}$ & $\begin{array}{l}.903 \\
60\end{array}$ & $\begin{array}{l}.921 \\
40\end{array}$ \\
\hline
\end{tabular}

NOTE.-See table 2 for definition of variables. Absolute value of $t$-statistics in parentheses. 
to be less than zero and this implies that an increase in the serial correlation parameter should decrease the probability of observing an indexed contract. In fact, we observe this result.

Third, an increase in residual uncertainty appears to reduce the probability of indexed contracts. This result is consistent with the theoretical result that degree of indexing declines with increased residual uncertainty, when the optimal degree of indexing is less than unity and employee relative risk aversion is greater than employer relative risk aversion. Where statistically significant, increased residual uncertainty also increases the industry layoff rate, a result consistent with a priori expectations.

Fourth, an increase in the expected growth of demand reduces the industry layoff rate as might be expected and, where significant, appears to increase the probability of indexed contracts. One can show, from (21), that the effect of an increase in the expected growth of demand on wage indexing is of the same sign as $\left(A^{*}-A\right)(1-S)$. Since it is likely that $A^{*}>A$ (see Sec. IV), this result is consistent with employees' relative risk aversion's $(S)$ being less than unity. ${ }^{30}$ Finally, where statistically significant, the greater the percentage of family income attributable to the wage earnings of the union member, the greater the probability of COLA coverage. In terms of the discussion in Section II, this suggests that other forms of family income tend to be fixed in real rather than nominal terms.

Numerous associations between the other explanatory variables, COLA coverage, and the layoff rate are also found. The reader is referred to our longer paper for a discussion of these findings. While the results presented there and in this section cannot be described as totally unambiguous, they do generate some support for the relevance of the models that we developed in earlier sections.

\section{Empirical Analyses: Individual Contract Data}

Cost-of-living provisions vary widely across union contracts, on a number of dimensions. For example, they vary in the frequency of review. Some contracts call for quarterly reviews and adjustments of wages, some for semiannual reviews, and still others for annual ones. Some allow for a COLA increase in the initial year of the contract, while others do not. Other things equal, the earlier the first adjustment and the more frequent the reviews, the greater the "yield" of the COLA. That is, the more complete indexing will be.

Cost-of-living adjustment provisions also vary in their generosity per review. Some specify minimum price increases before any cost-of-living wage increase is granted. Others specify maximum COLAs, or "caps." Still others specify bands of price increases (e.g., $5 \%-6 \%$ ) for which no

${ }^{30}$ Some studies, however, find that relative risk aversion exceeds unity. See, e.g., Friend and Blume 1975; Farber 1978. 
COLA wage increases will be granted. Clearly, such provisions affect the yield of a COLA.

Increases are typically specified as a 1-cent increase in wages for each fractional point increase in the consumer price index. Among 102 major union contracts in 1979, this fraction varied between .3 and .6 (see AFL-CIO 1979). Larger fractions obviously represent less generous COLAs. The generosity of a COLA provision also depends on the level of earnings of the covered employees. Since COLAs typically are specified in absolute terms (so many cents per hour), the higher the earnings of employees, other things equal, the less generous a COLA will be.

There are a number of strategies one might follow to ascertain the generosity of a COLA provision. First, one might estimate the ex ante degree of indexing by the ex post degree of indexing-the elasticity of wages with respect to inflation that actually occurred. This is the approach followed by Hendricks and Kahn (1983).

Its weakness is that, given the complex way COLAs are formulated, this number will typically depend nonlinearly on both the actual level of inflation and the various COLA provisions. Since the elasticity of wages with respect to inflation typically varies with the level of inflation, it is unclear whether one should attempt to summarize the provisions of a COLA by this single number. Furthermore, such a number at best would be an average ex post elasticity; it would tell us nothing about the marginal effect of inflation on wages. Indeed, it is not difficult to think of circumstances in which contract $A$ shows a greater COLA increase than contract $B$, given the actual inflation rate that occurred, but where the marginal COLA increase for increments of inflation would be larger in $B$ than in $A$ because of a cap on the COLA increase in $A$. It is unclear in such a case which contract has the more generous COLA provision.

A second approach is to argue that it is difficult to disentangle COLA increases from the portion of deferred noncontingent wage increases that are implicitly based on expectations of inflation. Indeed, if intracontract real-wage changes are generally small, one might treat them as zero and argue that the sum of the percentage deferred wage increases and the COLA increases that occurred ex post, divided by the ex post inflation rate, is a good measure of the ex ante elasticity of wages with respect to prices.

The theoretical models we presented in Sections IV and V suggest that such an approach may be incorrect; it is possible to model both the determinants of COLA increases and of deferred increases. Moreover, a simple numerical example illustrates the empirical difficulties inherent in such an approach. Consider two contracts. Suppose that the first calls for a $5 \%$ deferred increase and no COLA increase, while the second calls for no deferred increase, but a 1\% COLA increase for each $1 \%$ increase in prices. If the ex post increase in prices was $5 \%$, the two would yield 
equal percentage increases in wages and, if the ex ante increase in prices was also $5 \%$, the two would also yield equal expected wage increases. However, the former would provide workers with no protection against unanticipated inflation, while the latter would provide them with complete protection. Since we and Card (1981) have argued that a major motivation for COLAs is their risk-sharing provisions, in particular the sharing of risks due to unanticipated inflation, it seems strange to argue that the two contracts offer equal COLA protection. ${ }^{31}$

A third approach, followed by Card (1982), is to argue that because of the interdependence between deferred and COLA increases, it makes little sense to focus on the overall ex post change in wages. Rather, Card measures the ex ante elasticity by the marginal elasticity of the wage escalator; the cents per point increase in the CPI that the escalator yields (while active) divided by the real contractual wage at the start of the contract. The weakness of this approach, of course, is that it ignores the presence of caps, nonlinearities, and so on. For example, two contracts may initially offer the same COLA payment per point increase in the CPI, but if one has a cap on the maximum size of the COLA payment and the other does not, one would not want to argue that both offer equal COLA protection. The weakness of Card's measure then lies in the restriction, "while active."

The discussion above suggests that it may be inappropriate-indeed, nearly impossible-to summarize all of the information about the generosity of a contract's COLA provisions in a single number. Hence, the strategy we followed in our longer paper was to use information on a whole vector of contract provisions that we obtained from individual manufacturing collective bargaining agreements covering more than 1,000 workers that were on file with the Bureau of Labor Statistics in 1981. These provisions included whether there was a COLA provision, how frequent COLA reviews were, whether there was a review in the first year of the contract, the number of cents or percentage wage increase a worker would receive under a COLA for a given increase in the CPI, the presence of guaranteed minimum COLA increases and caps (or maximum COLA increases), and the duration of the underlying contract. Each of these variables was related to a vector of explanatory variables suggested by our models that were similar to the vector used in Section VII, and the resulting equations were estimated using individual contract data and appropriate estimation methods (the dependent variables included dichotomous and truncated ones).

Each of these variables provides information on the existence of a

${ }^{31}$ Our discussion of these two approaches should make it clear why we consider it equally inappropriate to use the expected COLA increase, valued at the expected level of inflation over the contract, as a measure of the generosity of a COLA; this measure tells us little about the response of wages to unanticipated inflation. 
COLA, its generosity, or the duration of the underlying contract. A stringent test of our models, then, is to look at the coefficients of a given explanatory variable across equations and to see if a consistent pattern of results is present: that is, Does it appear that a given variable is influencing each of the outcomes in a way that is consistent with the underlying theoretical models?

Details of the form of these equations and a table of results appear in Ehrenberg et al. (1982). The results can at best be described as mixed and do not provide strong support for the validity of our theoretical models. An explanation may lie in our method of testing. It may be unreasonable to expect that one can estimate the effect of an explanatory variable on 10 different dimensions of a COLA provision and hope to observe a consistent pattern of coefficients across equations. After all, the theoretical models provide hypotheses about the elasticity of wages with respect to prices, not about timing of reviews, minimum increase, caps, and so forth. While we believe our criticisms of the approaches of previous investigators are valid, the approach we describe in this section obviously has its own problems.

\section{Concluding Remarks}

This paper has presented a series of theoretical models that sought to ascertain the determinants of COLA provisions in union contracts, the generosity of these provisions when they exist, the magnitude of deferred wage increases that are not contingent on the price level, the duration of labor contracts, and the level of temporary layoffs. The factors highlighted were varied and encompassed characteristics of the firm's demand curve (including how it responds to unanticipated inflation), employee and employer risk aversion, characteristics of the bargaining relationship (including the costs of concluding negotiations), macroeconomic variables, and parameters of the unemployment insurance system.

Two initial empirical tests of the hypotheses generated by the models were provided. The first test used data at the two-digit manufacturing industry level of aggregation and focused on the determinants of the fraction of workers covered by COLA provisions and on the industry layoff rate. This analysis, which made use of pooled cross-section timeseries data, appeared to confirm a number of key implications of the models. The second test used data at the individual collective bargaining agreement level and focused on the determinants of COLA coverage, the characteristics of COLA agreements when they exist, and the duration of labor contracts. Unfortunately, the results here were much more mixed and did not provide strong support for the models.

In spite of the mixed nature of these results, we believe our paper has demonstrated the usefulness of analyzing the determinants of these union 
contract provisions in the context of risk-sharing models. Numerous extensions suggest themselves. At the empirical level, it is clear that better measures of the ex ante degree of indexing must be devised. Neither the single parameter measures used by Card (1981) and Hendricks and Kahn (1983), based on ex ante marginal elasticities over an initial range and ex post wage increases, respectively, nor the multiple parameter measures used by us seem to be appropriate. At the very least, what is required is a two-parameter measure that contains information on both the expected COLA wage increase and the marginal change in the wage increase that would result from unanticipated inflation.

We have also only begun to test the implications of the models. One productive line of testing would focus on the trade-off between COLA increases and deferred noncontingent wage increases. Much more work also needs to be done on the determinants of contract duration and on the effects of UI parameters (both replacement rates and experience rating) on the COLA-layoff trade-off.

At the theoretical level, an important unresolved issue is why COLA provisions typically take the form of " $X$ cents per one point increase in the CPI" rather than " $X \%$ increase in wages for each percentage increase in the CPI." As is well known, the first form will tend to compress wage differentials within a firm, while the second will keep them constant. What is needed here are models of union decision-making processes that highlight how heterogeneity of union members and different voting schemes will lead to different types of contract provisions. Ultimately, such theoretical modeling should lead to empirical research on the determinants of the type of COLA provision adopted.

Similarly, the minimum price increases that are required before COLA coverage starts in some contracts and the caps or maximum increases in others suggest that risk-sharing agreements often exist only over a subset of possible states of the world. It may be useful to try to model the conditions that lead to such restrictions and then to test the usefulness of such models empirically.

\section{References}

AFL-CIO. Comparative Survey of Major Collective Bargaining Agreements, March 1979. Washington: AFL-CIO, December 1979.

Azariadis, Costas. "Escalator Clauses and the Allocation of Cyclical Risks." Journal of Economic Theory 18 (June 1978): 119-55.

Baily, Martin B. "On the Theory of Layoffs and Unemployment." Econometrica 45 (July 1977): 1043-63.

Barro, Robert J. "Long-Term Contracting, Sticky Prices and Monetary Policy." Journal of Monetary Economics 3 (1977): 306-16.

Blanchard, Olivier. "Wage Indexing Rules and the Behavior of the Economy." Journal of Political Economy 87 (August 1979): 798-815. 
Card, David. "Wage Indexation in Labor Contracts and the Measurement of Escalation Elasticities." Mimeographed. Princeton, N.J.: Princeton University, October 1981.

"Cost-of-Living Escalators in Major Union Contracts." Mimeographed. Princeton, N.J.: Princeton University, March 1982.

Danziger, Leif. "Risk Sharing in Labor Contracts." European Economic Review 14 (1980): 323-40.

"On the Frequency of Wage Indexation." European Economic Review (1983), in press.

Douty, H. M. Cost-of-Living Escalator Clauses and Inflation. Washington: Council on Wage and Price Stability, 1981.

Ehrenberg, Ronald G.; Danziger, Leif; and San, Gee. "Cost-of-Living Adjustment Clauses in Union Contracts." National Bureau of Economic Research Working Paper no. 998. Cambridge, Mass. : National Bureau of Economic Research, October 1982 (forthcoming in Research in Labor Economics).

Estenson, David. "Relative Price Variability and Indexed Labor Agreements." Industrial Relations 20 (Winter 1981): 871-84.

Farber, Henry. "Individual Preferences and Union Wage Determination: The Case of the United Mine Workers." Journal of Political Economy 86 (October 1978): 923-42.

. "The Determination of Negotiated Wage Changes: A Reference Wage Approach.” Mimeographed. Cambridge, Mass.: MIT, September 1981.

Feldstein, Martin. "Temporary Layoffs in the Theory of Unemployment." Journal of Political Economy 84 (October 1976): 937-58.

Fisher, Stanley. "Long-Term Contracting, Sticky Prices and Monetary Policy: A Comment." Journal of Monetary Economics 3 (1977): 31724. (a)

"Wage Indexation and Macroeconomic Stability." Journal of Monetary Economics 5 (Suppl. 1977): 107-47. (b)

Friend, Irwin; and Blume, Marshall. "The Demand for Risky Assets." American Economic Review 65 (December 1975): 900-922.

Gray, Jo Anna. "Wage Indexation: A Macroeconomic Approach." Journal of Monetary Economics 2 (April 1976): 221-35.

- "On Indexation and Contract Length." Journal of Political Economy 86 (February 1978): 1-18.

Hendricks, Wallace, and Kahn, Lawrence. "Determinants and Effects of Cost-of-Living Allowance Coverage in U.S. Collective Bargaining Agreements." Industrial and Labor Relations Review 36 (April 1983): 447-60.

Kahn, Lawrence. "Wage Indexation and Wage Inflation in the U.S." Mimeographed. Urbana-Champaign: University of Illinois, May 1981.

Kaufman, Bruce E. "Bargaining Theory, Inflation and Cyclical Strike Activity in Manufacturing." Industrial and Labor Relations Review (April 1981).

Kosters, Marvin. "Wage and Price Behavior: Prospects and Policies." In 
Contemporary Economic Problems, edited by William Fellner. Washington: American Enterprise Institute, 1977.

LeRoy, Douglas. "Scheduled Wage Increases and Cost-of-Living Provisions in 1981." Monthly Labor Review 104 (January 1981): 6-12.

Marshall, Alfred. Reply to the Royal Commission on the Repression of Trade and Industry (1866). In Official Papers by Alfred Marshall. London: Macmillan, 1886.

Mauro, Martin. "Strikes As a Result of Imperfect Information." Industrial and Labor Relations Review 35 (July 1982): 522-39.

Mitchell, Daniel. "Union Wage Determination: Policy Implications and Outlook." Brookings Papers on Economic Activity, no. 3 (1978), pp. 537-82. 1980.

Shavell, Steven. "Sharing Risks of Deferred Payments." Journal of Political Economy 84 (February 1976): 161-68.

Shefer, Victor. "Cost-of-Living Adjustments: Keeping up with Inflation." Monthly Labor Review 102 (June 1979): 14-17.

Svejnar, Jan. "Bargaining Power, Fear of Disagreement and Wage Settlements: Theory and Empirical Evidence from U.S. Industry." Mimeographed. Ithaca, N.Y.: Cornell University, June 1982.

Tobin, James. "Stabilization Policy Ten Years After." Brookings Papers on Economic Activity, no. 1 (1980), pp. 19-72.

Vroman, Wayne. "A Simulation Model of Unemployment Insurance." In Compendium, by the National Commission on Unemployment Compensation. Washington: Government Printing Office, 1980.

- "Escalator Clauses and Price-Wage Feedback in the U.S. Economy." Mimeographed. Washington: Urban Institute, 1982. 